\title{
Investigation of the Potential for Binding of Di(2-ethylhexyl) Phthalate (DEHP) and Di(2-ethylhexyl) Adipate (DEHA) to Liver DNA in Vivo'
}

\author{
ALBERT VON DÄNIKEN, WERNER K. LUTZ, ${ }^{2}$ RUDOLF JÄCKH, ${ }^{3}$ \\ AND CHRISTIAN SCHLATTER \\ Institute of Toxicology, Swiss Federal Institute of Technology, and University of Zurich, \\ CH.8603 Schwerzenbach, Switzerland
}

Received June 9, 1983; accepted November 28, 1983

\begin{abstract}
Investigation of the Potential for Binding of Di(2-ethylhexyl) Phthalate (DEHP) and Di(2ethylhexyl) Adipate (DEHA) to Liver DNA in Vivo. VON DÄNIKEN, A., LUTZ, W. K., JÄCKH, R., AND SCHLATTER, C. (1984). Toxicol. Appl. Pharmacol. 73, 373-387. It was the aim of this investigation to determine whether covalent binding of di(2-ethylhexyl) phthalate (DEHP) to rat liver DNA and of di(2-ethylhexyl) adipate (DEHA) to mouse liver DNA could be a mechanism of action contributing to the observed induction of liver tumors after lifetime feeding of the respective rodent species with high doses of DEHP and DEHA. For this purpose, DEHP and DEHA radiolabeled in different parts of the molecule were administered orally to female rats and mice, respectively, with or without pretreatment for 4 weeks with $1 \%$ unlabeled compound in the diet. Liver DNA was isolated after $16 \mathrm{hr}$ and analyzed for radioactivity. The data were converted to a covalent binding index, $\mathrm{CBI}=$ (micromoles of substance bound per mole of DNA nucleotides)/(millimoles of substance applied per kilogram body weight), in order to allow a quantitative comparison also with other carcinogens and noncarcinogens. Administration of $\left[{ }^{14} \mathrm{C}\right]$ carboxylate-labeled DEHP to rats resulted in no measurable DNA radioactivity. The limit of detection, $\mathrm{CBI}<0.02$ was about 100 times below the $\mathrm{CBI}$ of compounds where an observable tumor-inducing potential could be due to genotoxicity. With $\left[{ }^{14} \mathrm{C}\right]-$ and $\left[{ }^{3} \mathrm{H}\right] \mathrm{DEHP}$ labeled in the alcohol moiety, radioactivity was clearly measurable in rat liver DNA. HPLC analysis of enzyme-degraded or acid-hydrolyzed DNA revealed that the natural nucleosides or purine bases were radiolabeled whereas no radioactivity was detectable in those fractions where the carcinogenmodified nucleoside or base adducts are expected. The respective limits of detection were at 0.07 and $0.04 \mathrm{CBI}$ units for the ${ }^{14} \mathrm{C}$ and ${ }^{3} \mathrm{H}$ labels, respectively. The experiments with $\left[{ }^{14} \mathrm{C}\right]$ - and [ $\left.{ }^{3} \mathrm{H}\right] \mathrm{DEHA}$, labeled in the alcohol moiety and administered to mice, revealed a minute radioactivity of $<50 \mathrm{dpm} / \mathrm{mg}$ liver DNA, too little to allow a nucleoside analysis to determine that fraction of the radioactivity which had been incorporated via biosynthesis. Expressed in the CBI units, values of 0.05 to 0.15 for ${ }^{14} \mathrm{C}$ and 0.01 to 0.12 for ${ }^{3} \mathrm{H}$ resulted. Determination of the level of ${ }^{14} \mathrm{CO}_{2}$ expiration revealed a linear correlation with the specific activity of DNA. Experiments with 2-ethyl[ $\left.1-{ }^{14} \mathrm{C}\right]$ hexanol performed with both rats and mice allowed the conclusion that most if not all DEHA radioactivity in mouse liver DNA was due to biosynthetic incorporation. A maximum possible true DNA binding by DEHA must be below CBI 0.01 . Pretreatment of the animals with unlabeled compound had no effect on the DNA radioactivities in either species. The present negative data, in conjunction with other negative short-term tests for mutagenicity, strongly indicate that covalent interaction with DNA is highly unlikely to be the mode of tumorigenic action of DEHP and DEHA in rodents.
\end{abstract}

The plasticizer di(2-ethylhexyl) phthalate (DEHP) was reported to induce liver tumors in F344 rats and B6C3F1 mice in a 2-year

\footnotetext{
' This work was supported by the European Plasticiser Manufacturers under the auspices of the European Council
}

of the Federation of the Chemical Industry (CEFIC) on behalf of the Bureaux Internationaux Techniques (BIT), Plasticiser Toxicology and Ecology Committee.

${ }^{2}$ To whom correspondence should be sent: Institute of Toxicology, CH-8603 Schwerzenbach, Switzerland.

${ }^{3}$ Present address: BASF Aktiengeselischaft, Institute of Toxicology, D-6700 Ludwigshafen FRG. 
feeding experiment (National Toxicology Program, 1982a). The doses used $(12,000$ and $6000 \mathrm{ppm}$ DEHP in the diet for the rats and 6000 and $3000 \mathrm{ppm}$ for the mice) caused increased incidences of hepatocellular carcinoma or neoplastic nodules in female rats of either dose group and in male rats of the higher dose group as well as hepatocellular carcinoma and adenoma in mice of either sex and dose group.

Di(2-ethylhexyl) adipate (DEHA) was reported to induce liver tumors in mice in a 2year feeding experiment with $12,000 \mathrm{ppm}$ and 25,000 ppm DEHA admixed to the diet (National Toxicology Program, 1982b). Increased incidences of hepatocellular adenoma and carcinoma in males and females were found in either dose group. In rats, no difference in incidence or type of tumors between treated and control animals was observed after a 2year feeding with 12,000 or $25,000 \mathrm{ppm}$ DEHA in the diet.

Considering the widespread use of DEHP and DEHA and the possible exposure of the general population to low doses, it seems important to determine whether the tumor-inducing potential of these compounds is based upon a genotoxic mode of action via DNA binding or whether other mechanisms are responsible. The answer is essential for any extrapolation between species and from high to low doses.

DEHP and DEHA are inducers of peroxisomes in rats (Moody and Reddy, 1978; Reddy, 1981; Mangham et al., 1981; Gray et al., 1982). The peroxisome inducers may form a novel class of carcinogens (Reddy et al., 1980). On the other hand, data on a putative interaction of radiolabeled DEHP with rat liver DNA in vivo have been presented by Albro et al. (1982). In a subsequent report (Albro et al., 1983) which included data on dual label experiments, this group presented indirect evidence that the association of radiolabel with DNA might have been due to biosynthetic incorporation. The main limiting factor in their studies was the fact that the low level of DNA radioactivity allowed no analysis of the DNA constituents to distinguish between biosynthetic incorporation of the radiolabel and true covalent deoxyribonucleotide-DEHP adducts.

These preliminary findings prompted us to perform a DNA-binding assay with DEHP in rat and mouse liver and DEHA in mouse liver. Large amounts of radioactivity were administered in our study in order to achieve sufficiently high specific activities in the DNA to allow for an analysis of the source of the radiolabel and to improve the limit of detection in case of a negative result. The present study was carried out with DEHP and DEHA radioactively labeled in three different positions as illustrated in Fig. $1 . \mathrm{A}{ }^{14} \mathrm{C}$ label was introduced either at the carboxylate carbon atom of the phthalate moiety (I) or at C-1 of the alcohol moiety of DEHP (II) and of DEHA (V). $\left[{ }^{3} \mathrm{H}\right]$ DEHP II and $\left[{ }^{3} \mathrm{H}\right]$ DEHA VI were tritiated in positions 2 and 3 of the alcohol moiety. In order to investigate whether 2ethylhexanol (EH), a known metabolite of DEHP and DEHA, can interact with DNA, $\left[1-{ }^{14} \mathrm{C}\right] \mathrm{EH}$ IV was also studied.

The long-term exposure to DEHP and DEHA used in the carcinogenicity studies could have induced qualitative and/or quan-

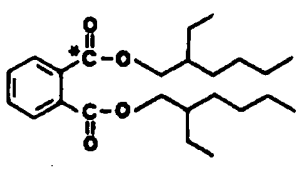

1

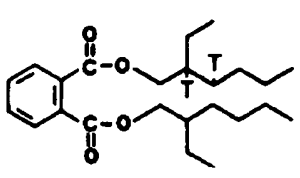

III

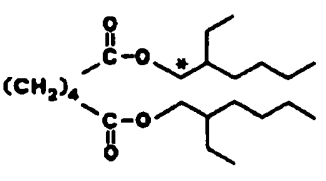

V

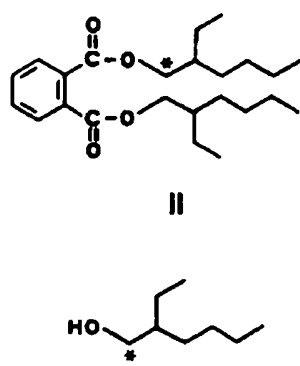

IV

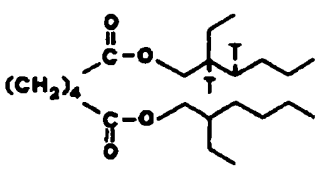

VI
FIG. 1. Structures of radiolabeled test compounds used. (I, II, III) Di(2-ethylhexyl) phthalate; (IV) 2-ethylhexanol; $\left(V\right.$, VI) di(2-ethylhexyl) adipate. $*={ }^{14} \mathrm{C}, \mathrm{T}={ }^{3} \mathrm{H}$. 
titative changes in the enzymatic drug metabolism pattern. In order to investigate whether such pretreatment could have an effect on DNA binding, groups of animals were pretreated for 4 weeks with a diet containing $10 \mathrm{~g} / \mathrm{kg}$ DEHP or DEHA.

\section{METHODS}

Chemicals and radiolabeled compounds. All enzymes were obtained from Sigma Chemical Company, St. Louis, Missouri. DEHP, ${ }^{14} \mathrm{C}$-labeled in the carboxylate carbon (Fig. 1, compound I) was synthesized at ICI, Macclesfield, UK, with a specific activity of $46.8 \mathrm{mCi} / \mathrm{mmol}$. DEHP and DEHA labeled with ${ }^{14} \mathrm{C}$ and ${ }^{3} \mathrm{H}$ in the alcohol moiety (II, II, V, and VI) were synthesized at BASF AG, Ludwigshafen, FRG, with specific activities of 39.5, 132.8, 38.9 , and $124.7 \mathrm{mCi} / \mathrm{mmol}$, respectively. The $\left[{ }^{14} \mathrm{C}\right] \mathrm{EH}$ IV was produced at BASF with a specific activity of 34.4 $\mathrm{mCi} / \mathrm{mmol}$. The radiochemical purity was checked 1 day before use by thin-layer chromatography on silica-gel plates with methylene chloride for DEHA and DEHP and methylene chloride:methanol 1:1 for EH. The radiochemical purity was $97.8 \%$ for $\left[{ }^{3} \mathrm{H}\right] \mathrm{DEHA}$ and $>99 \%$ for the other compounds. Unlabeled DEHP was obtained from Fluka AG, Buchs, Switzerland. The compounds were dissolved in olive oil (Konsum Verein, Zurich, Switzerland). One milliliter of the application solution of $\left[{ }^{14} \mathrm{C}\right] \mathrm{DEHP}$ I contained $136 \mathrm{mg}$ DEHP with $2.54 \mathrm{mCi}$. Compounds II and III were administered together to rats as a solution of 129 $\mathrm{mg} \mathrm{DEHP} / \mathrm{ml}$ with $1.12 \mathrm{mCi} / \mathrm{ml}$ of $\left[{ }^{14} \mathrm{C}\right] \mathrm{DEHP}$ and 9.86 $\mathrm{mCi} / \mathrm{ml}$ of $\left.{ }^{3} \mathrm{H}\right] \mathrm{DEHP}$. Compounds $\mathrm{V}$ and VI were administered together to mice as a solution of $119 \mathrm{mg} \mathrm{DEHA}$ / $\mathrm{ml}$ with $3.85 \mathrm{mCi} / \mathrm{ml}$ of $\left[{ }^{14} \mathrm{C}\right] \mathrm{DEHA}$ and $27.7 \mathrm{mCi} / \mathrm{ml}$ of $\left[{ }^{3} \mathrm{H}\right]$ DEHA. The ${ }^{14} \mathrm{C}$ to ${ }^{3} \mathrm{H}$ ratio was chosen to be about 1:8 because of different counting efficiencies and the ${ }^{14} \mathrm{C}$ spillover in the ${ }^{3} \mathrm{H}$ channel which reduces the accuracy of the determination of ${ }^{3} \mathrm{H}$ counts. $\left[{ }^{14} \mathrm{C}\right] \mathrm{DEHP}$ II was administered to mice as a solution of $26.4 \mathrm{mg} \mathrm{DEHP} / \mathrm{ml}$ olive oil with $2.67 \mathrm{mCi} / \mathrm{ml}$ of ${ }^{14} \mathrm{C}$ label. $\mathrm{EH} \mathrm{IV} \mathrm{was} \mathrm{used}$ undiluted. One milliliter of the application solution contained 12.0 and $11.0 \mathrm{mg} \mathrm{EH}$ with 3.15 and $2.91 \mathrm{mCi}{ }^{14} \mathrm{C}$ for the treatment of rats and mice, respectively.

Animals and treatments. Female rats of the Fischer 344 strain and female mice of the NMRI strain, 150-200 and 21-23 g body wt, respectively, were supplied by Charles River Wiga, Sulzfeld, FRG. They were held in Macrolone cages in groups of four animals and were marked by tail painting. Room temperature of $21 \pm 2^{\circ} \mathrm{C}$ and humidity of $55 \pm 15 \%$ were registered continuously. The illumination time was $12 \mathrm{hr}$ per day. The animals were fed with diet No. 343 purchased from Kliba Klingentalermühle, Kaiseraugst, Switzerland (Batcb Nos. 55/81 and 59/82). Analysis of contaminants of feed was performed by RCC, Itingen, Switzerland, and conformed to EPA specifications of maximally tolerable levels. The pretreated groups were fed a diet containing $10 \mathrm{~g} / \mathrm{kg}$ DEHP and DEHA, respectively, prepared and analyzed with respect to concentration, stability, and homogenity by BASF. Feed and water were given ad libitum. Feed consumption was measured daily. The body weight was monitored weekly.

After 2 to 3 weeks of acclimatization, one group of animals was given the DEHP- or DEHA-containing diet for 4 weeks while the others received the regular chow. The radiolabeled test compounds were then administered by oral gavage of the solutions described above on dose levels indicated in the tables. For each experiment two animals served as unlabeled controls and were treated with no radioactivity at all.

Pharmacokinetics. After the administration of the radiolabeled compounds, the animals were held in all-glass metabolism cages, and urine was collected. An air stream of $0.4 \mathrm{liter} / \mathrm{min}$ transported the expired air to a trap with ethanolamine:methanol $1: 4$ to collect the ${ }^{14} \mathrm{CO}_{2}$ expired. The production of tritiated water, HTO, from $\left[{ }^{3} \mathrm{H}\right] \mathrm{DEHP}$ was determined on the basis of the specific activity of the HTO in the urine after dilution with water and repeated recondensation.

Isolation of DNA. Sixteen hours after the administration of the radiolabeled compounds, the animals were killed by open heart puncture under ether anesthesia, and livers were excised and weighed. A crude chromatin fraction was prepared in the cold by a slightly modified method described by Yaneva and Dessev (1976): The liver was homogenized in $75 \mathrm{mM} \mathrm{NaCl}, 10 \mathrm{mM}$ EDTA, $10 \mathrm{mM}$ Tris/HCl, pH 7.8, in a Potter-Elvehjem homogenizer. Nonidet P-40 detergent was added to a concentration of $0.2 \%$. After $15 \mathrm{~min}$, the samples were centrifuged for 5 min at $700 \mathrm{~g}$. The crude chromatin pellet was washed once with $10 \mathrm{mM}$ EDTA, $10 \mathrm{mM}$ Tris/HCl, pH 7.8. The isolation and purification of DNA from chromatin at room temperature followed the standard method used in our laboratory, which is based on a method of two extractions with phenol:chloroform:isoamyl alcohol 25:24:1 and a hydroxylapatite column chromatography as the main purification step (Markov and Ivanov, 1974). After dialysis against water at $4^{\circ} \mathrm{C}$ overnight, addition of $\mathrm{NaCl}$ to a concentration of $0.2 \mathrm{M}$ and precipitation after addition of a twofold volume of ethanol, the DNA was dried on an aspirator vacuum and dissolved in 4 or $5 \mathrm{ml}$ of 10 $\mathrm{mM}$ Tris/HCl, $10 \mathrm{mM} \mathrm{MgCl}$, $\mathrm{pH}$ 7.0. In the experiment with mice the ethanol precipitation step was repeated once. The DNA content was determined on the basis of a uv absorbance of 20 at $260 \mathrm{~nm}$ for a solution of $1 \mathrm{mg} / \mathrm{ml}$. An aliquot of $1 \mathrm{ml}$ was used for radioactivity counting. If no radioactivity was measurable, the remaining DNA solution was added to the vial and counted again. If radioactivity was detectable on a level of at least $50 \mathrm{cpm} /$ mg, DNA was degraded enzymatically or depurinated with hydrochloric acid, and the deoxyribonucleosides or purine bases were separated by HPLC to determine biosynthetic incorporation of radioactivity into the DNA. 
Determination of covalent binding indices (CBI). The specific radioactivity of DNA was normalized by the dose administered:

$$
\mathrm{CBI}^{\prime}=\frac{\mathrm{dpm} / \mathrm{mg} \text { DNA }}{\mathrm{dpm} / \mathrm{kg} \text { body } w \mathrm{t}}
$$

This value was converted to the molar units,

$$
\mathrm{CBI}=\frac{\mu \mathrm{mol} \text { chemical bound } / \mathrm{mol} \text { DNA nucleotide }}{\text { mmol chemical applied } / \mathrm{kg} \text { body } \mathrm{wt}} \text {, }
$$

according to $\mathrm{CBI}=\mathrm{CBI}^{\prime} \times 309 \times 10^{6}$ on the basis of an average molecular weight of $309 \mathrm{~g} / \mathrm{mol}$ DNA nucleotides (Lutz, 1979).

Analysis of deoxyribonucleosides. DNA was degraded enzymatically to deoxyribonucleosides by a method slightly modified from King et al. (1977): 1-2 mg of DNA dissolved in $1 \mathrm{ml} 10 \mathrm{mM}$ Tris/ $\mathrm{HCl}, 10 \mathrm{mM} \mathrm{MgCl}_{2}, \mathrm{pH} 7.0$, was incubated for $16 \mathrm{hr}$ at $37^{\circ} \mathrm{C}$ with 250 units of deoxyribonuclease I (EC 3.1.21.1) from bovine pancreas. Two hundred fifty microliters with 0.075 unit venom phosphodiesterase I (EC 3.1.4.1) and 2.5 units of alkaline phosphatase III (EC 3.1.3.1) from Escherichia coli in a solution of $50 \mathrm{mM}$ Tris/ $\mathrm{HCl}, \mathrm{pH} 9.0$, were added and incubated for $24 \mathrm{hr}$ at $37^{\circ} \mathrm{C}$. After filtration through $0.22-\mu \mathrm{m}$ filters (Millipore, Bedford, Mass.), the samples were loaded onto a HPLC reverse-phase column (LiChrosorb RP 18, $8 \times 250$ $\mathrm{mm}$, Knauer, Oberursel, FRG) and eluted with a flow of $3.5 \mathrm{ml} / \mathrm{min}$ for $56 \mathrm{~min}$ with a methanol:water gradient $0-10 \%$ for the first $5 \mathrm{~min}, 10-100 \%$ from 10 to $50 \mathrm{~min}$. The optical density at $254 \mathrm{~nm}$ of the eluate was continuously recorded in a flow photometer (Perkin-Elmer LC55). Fractions of $7 \mathrm{ml}$ were collected (unless indicated otherwise in Fig. 7) and added to $10 \mathrm{ml}$ Insta-Gel (Packard) for radioactivity counting.

The background radioactivity in the ${ }^{14} \mathrm{C}$ channel was determined for each chromatogram on the basis of mean and standard deviation of fractions 1 and 11-28. The background radioactivity in the ${ }^{3} \mathrm{H}$ channel is not constant over the entire chromatogram due to the quenching by a higher methanol content in the later fractions. The background radioactivity of the first 12 fractions and the respective standand deviation were therefore determined with linear regression of the cpm values of fractions $1,3,4,8$, 9,11 , and 12. The background radioactivity of fractions 13-28 was determined on the basis of the mean and standard deviation of these single fractions obtained from control DNA.

Analysis of purine bases. The DNA was depurinated by acid hydrolysis. $\mathrm{HCl}(1 \mathrm{M})$ was added to the DNA solution to give a concentration of $0.1 \mathrm{M}$. The samples were incubated for $1 \mathrm{hr}$ at $70^{\circ} \mathrm{C}$ (Meier-Bratschi et al., 1983). After the samples were filtered through $0.22-\mu \mathrm{m}$ filters, they were loaded onto an HPLC reverse-phase column, $\mu$ Bondapack $\mathrm{C}_{18}(7.8 \times 300 \mathrm{~mm}$, Waters), and eluted with $3.5 \mathrm{ml} / \mathrm{min} 0.01 \mathrm{M}$ ammonium phosphate, $\mathrm{pH} \mathrm{4}$, with $1 \%$ methanol. The elution was monitored at 254 $\mathrm{nm}$. Two-minute fractions of $7 \mathrm{ml}$ were collected and added to $10 \mathrm{ml}$ Insta-Gel for radioactivity counting.
The background radioactivity in the ${ }^{14} \mathrm{C}$ and ${ }^{3} \mathrm{H}$ channels was determined for each chromatogram on the basis of the mean and standard deviation of fractions $1,4,5,7$, 8, and 10-27.

Scintillation counting: Statistics. The radioactivity counting was carried out in a liquid scintillation counter, Tri-Carb 460 CD (Packard), with Insta-Gel (Packard) as the scintillation mixture. For small amounts of radioactivity, the samples were counted $4 \times 40 \mathrm{~min}$. The background was determined as the mean count of two DNA samples isolated together with the test samples from animals which had not received radiolabels but which were beld together with the test animals. These values, given in the tables and figures, varied between the experiments with standard deviations of $\pm 1.1 \mathrm{cpm}$ and $\pm 0.8 \mathrm{cpm}$ in the ${ }^{14} \mathrm{C}$ and ${ }^{3} \mathrm{H}$ channels, respectively (statistical mean of standard deviations within each pair of background counts) (Kaiser, 1965). This standard deviation was also used to decide whether significant radioactivity was detected in the vial containing DNA of treated animals. The counting efficiencies varied with the quench grade of the samples and were determined with internal standards. They are given in footnotes to the tables.

\section{RESULTS}

\section{General Observations and Pharmacokinetic Parameters}

In the rat. Feed consumption did not differ between the pretreated and the nonpretreated rats. The daily feed intake in the respective groups was $12.2 \pm 1.2$ and $13.8 \pm 2.1 \mathrm{~g}$ per rat, resulting in a DEHP dose for the pretreated rats of $0.65 \pm 0.05 \mathrm{~g} / \mathrm{kg}$ body wt per day. No deviation from the normal body weight gain known for this strain was observed.

The pretreatment of rats with DEHP in the feed $(10 \mathrm{~g} / \mathrm{kg})$ for 4 weeks increased the liver weight to body weight ratio significantly, a finding which is in accordance with other reports (Carpenter et al., 1953; Harris et al., 1956; Moody and Reddy, 1978). It was 56.2 $\pm 2.4 \mathrm{~g} / \mathrm{kg}$ body wt compared to $41.3 \pm 3.9$ $\mathrm{g} / \mathrm{kg}$ body wt of the nonpretreated rats. The liver enlargement resulted in a more rapid metabolism of the subsequent dose of radiolabeled DEHP as is illustrated by the more rapid and more extensive exhalation of ${ }^{14} \mathrm{CO}_{2}$ generated by the degradation of ${ }^{14} \mathrm{C}$-labeled DEHP I and II (see below). 


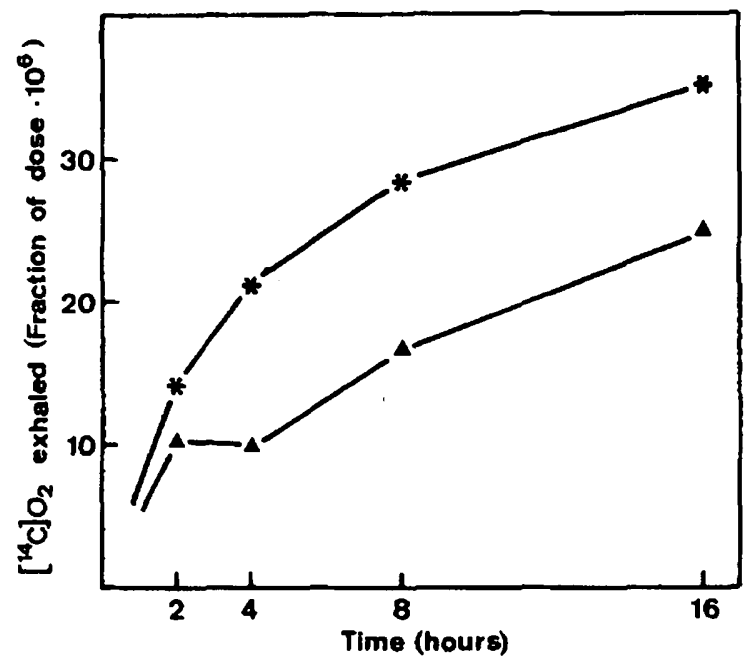

FIG. 2. Cumulative exhalation of ${ }^{14} \mathrm{CO}_{2}$ after oral administration of $\left[{ }^{14} \mathrm{C}\right]$ DEHP I to DEHP-pretreated $(*)$ and nonpretreated $(\Lambda)$ rats. Means of two animals.

About one-third of the radioactive dose of all four compounds was excreted within 16 $\mathrm{hr}$ in the urine. By taking into account the additional metabolites still present in the body, it is reasonable to assume that at least half the dose had been absorbed from the gastrointestinal tract and passed the liver.

Exhalation of ${ }^{14} \mathrm{CO}_{2}$ by the rats treated with the carboxylate-labeled DEHP I accumulated within $16 \mathrm{hr}$ to less than a fraction of $3 \times 10^{-5}$ of the radioactivity administered (Fig. 2). This finding is so small that it does not have to be the result of a metabolic cleavage of the carboxylate carbon of DEHP I from its benzene moiety, but could be due to radiolabeled impurities. The ${ }^{14} \mathrm{CO}_{2}$ exhalation after administration of alcohol-labeled DEHP II is, however, in the order of a few percent of the dose (Fig. 3). DEHP pretreatment resulted in an increased production of ${ }^{14} \mathrm{CO}_{2}$. After administration of $1-{ }^{14} \mathrm{C}$-labeled 2-ethylhexanol IV, the fraction of expired ${ }^{14} \mathrm{CO}_{2}$ represented as much as $15 \%$ (Fig. 4).

In the mouse. Feed consumption was slightly but not significantly increased in DEHA-pretreated mice. The daily feed intake in the respective groups was $7.12 \pm 1.75$ and $5.44 \pm 0.84 \mathrm{~g}$ per mouse, resulting in a DEHA dose for the pretreated mice of $2.09 \pm 0.57$ $\mathrm{g} / \mathrm{kg}$ body wt per day. No deviation from the

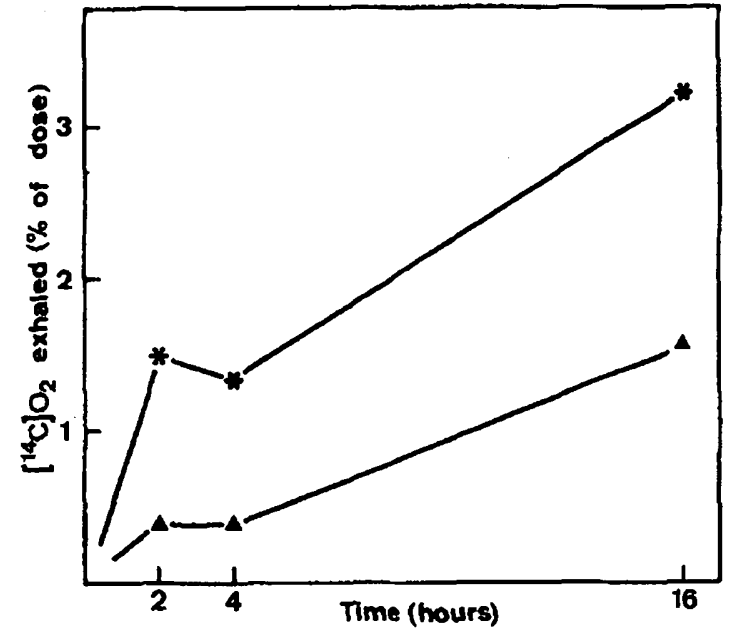

FIG. 3. Cumulative exhalation of ${ }^{14} \mathrm{CO}_{2}$ after oral administration of $\left[{ }^{14} \mathrm{C}\right] \mathrm{DEHP}$ II to DEHP-pretreated (*) and nonpretreated $(\Delta)$ rats. Means of two animals.

normal body weight gain known for this strain was observed.

The DEHA radioactivity excreted in the urine within $16 \mathrm{hr}$ was $60 \pm 29$ and $57 \pm 28 \%$ of the ${ }^{14} \mathrm{C}$ and ${ }^{3} \mathrm{H}$ doses administered. By taking into account the additional metabolites still present in the body, it is reasonable to assume that most of the radiolabeled dose had been absorbed from the gastrointestinal tract and had passed the liver.

Production of tritiated water (HTO) from

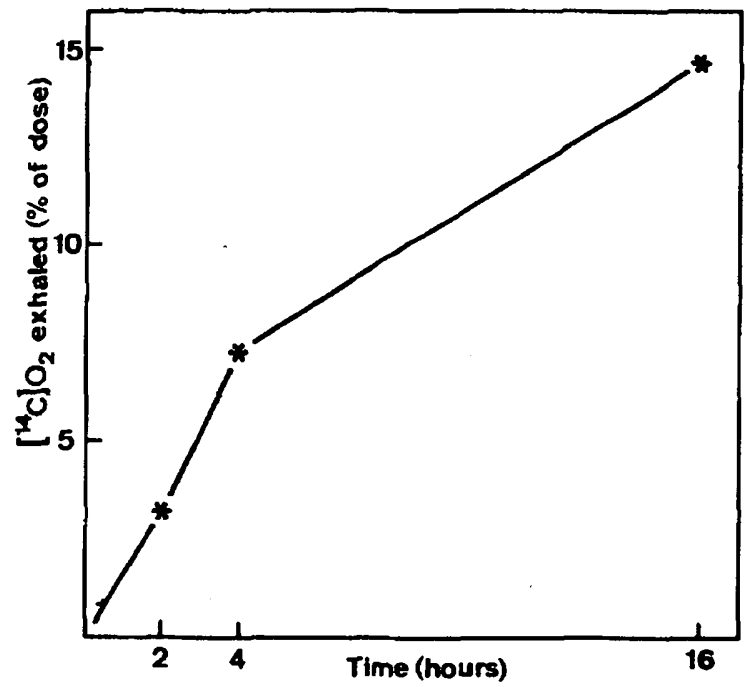

FIG. 4. Cumulative exhalation of ${ }^{14} \mathrm{CO}_{2}$ after oral administration of $\left[{ }^{14} \mathrm{C}\right] \mathrm{EH}$ IV to DEHP-pretreated rats. Means of two animals. 
$\left[{ }^{3} \mathrm{H}\right]$ DEHA was determined on the basis of the specific activity of HTO in the urine, which was between 1 and $4 \times 10^{7} \mathrm{dpm} / \mathrm{ml}$. Under the assumption that HTO is distributed homogeneously in the body fluid and that the total water content of a mouse is $60 \%$ of its body weight, 3 and $1.5 \%$ of the dose had been released as HTO in pretreated and nonpretreated animals, respectively.

The ${ }^{14} \mathrm{CO}_{2}$ exhalation after administration of ${ }^{14} \mathrm{C}$-labeled DEHA, DEHP, and EH was in the order of a few percent of the dose. DEHA pretreatment resulted in an increased production of ${ }^{14} \mathrm{CO}_{2}$. The exhalation of ${ }^{14} \mathrm{CO}_{2}$ after administration of $\left[{ }^{14} \mathrm{C}\right] \mathrm{EH}$ was more rapid than that of DEHA and was more extensive (Fig. 5).

The pretreatment of mice with DEHA in the food $(10 \mathrm{~g} / \mathrm{kg})$ for 4 weeks increased the liver weight to body weight ratio slightly but not significantly. It was $78 \pm 24 \mathrm{~g} / \mathrm{kg}$ body wt as compared to $61 \pm 14 \mathrm{~g} / \mathrm{kg}$ body wt of the nonpretreated mice. The more rapid metabolism of the radiolabeled DEHA, illustrated by an increased exhalation of ${ }^{14} \mathrm{CO}_{2}$, a more rapid excretion of radiolabel in the urine, and an increased HTO production, is probably due to this liver enlargement.

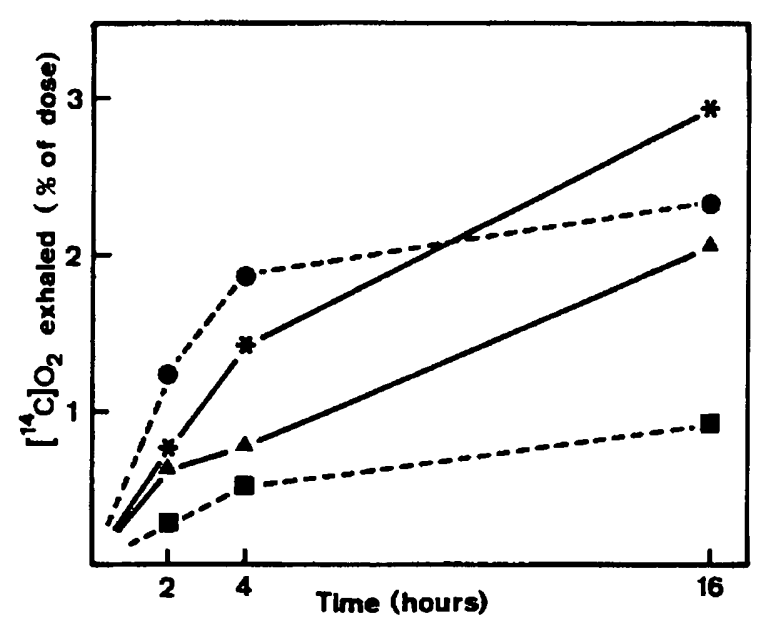

FIG. 5. Cumulative exhalation of ${ }^{14} \mathrm{CO}_{2}$ after oral administration of $\left[{ }^{14} \mathrm{C}\right] \mathrm{DEHA} I$ to DEHA-pretreated $(*)$ and nonpretreated (A) mice, of $\left[{ }^{14} \mathrm{C}\right] \mathrm{EH}$ IV $(\Theta)$ to DEHApretreated mice, and of $\left[{ }^{14} \mathrm{C}\right] \mathrm{DEHP}$ III ( $(\square)$ to nonpretreated mice (dashed lines). Means of two animals.

\section{DNA-Binding Studies in the Rat}

The data on the radioactivity determined in the DNA are summarized in Table 1. With carboxylate-labeled DEHP I, minute radioactivity could be detected in only one of four DNA samples. In all other samples, irrespective of the DEHP pretreatment, the radioactivity was below the limit of detection of the order of $0.02 \mathrm{CBI}$ unit. In one case, a small amount of radioactivity was detected in the DNA. It is very unlikely that this radioactivity originated from a radioactive labeled DNAphthalate adduct. Probably it is noncovalently bound radioactivity from contaminating proteins or labeled metabolites which may not have been completely removed in this specific sample. Our negative finding is in accordance qualitatively with that of Albro et al. (1982) who also did not find any radioactivity in the DNA after oral administration of carboxylatelabeled $\left[{ }^{14} \mathrm{C}\right] \mathrm{DEHP}$. Due to the fact that they administered only about $6.6 \times 10^{8} \mathrm{dpm} / \mathrm{kg}$, i.e., about 20 times less than the dose used in our study, their finding is less valuable, however, on a quantitative basis for an exclusion of a genotoxic activity.

When the label was in the alcohol moiety (DEHP II and III), radioactivity was easily detected in all samples, regardless of whether the label was ${ }^{14} \mathrm{C}$ or ${ }^{3} \mathrm{H}$. Apparent binding indices of 3 and 0.5 were obtained for the ${ }^{14} \mathrm{C}$ and ${ }^{3} \mathrm{H}$ labels, respectively, and pretreatment was without influence. After administration of $\left[{ }^{14} \mathrm{C}\right] \mathrm{EH} \mathrm{IV}$, the radioactivity in the DNA was about twice the respective value obtained from $\left[{ }^{14} \mathrm{C}\right] \mathrm{DEHP}$ II administration and apparent binding indices of about 6 resulted.

The radioactivity associated with the DNA samples could be due to noncovalent interaction of the compound or some metabolite with DNA, to biosynthetic incorporation of radiolabeled precursors of DNA synthesis, or to true covalent adducts with DNA. Contamination of the DNA with radiolabeled protein cannot contribute substantially to the DNA radioactivity because the specific activity of chromatin protein was only about 50 times 
LACK OF DNA BINDING OF DEHP AND DEHA

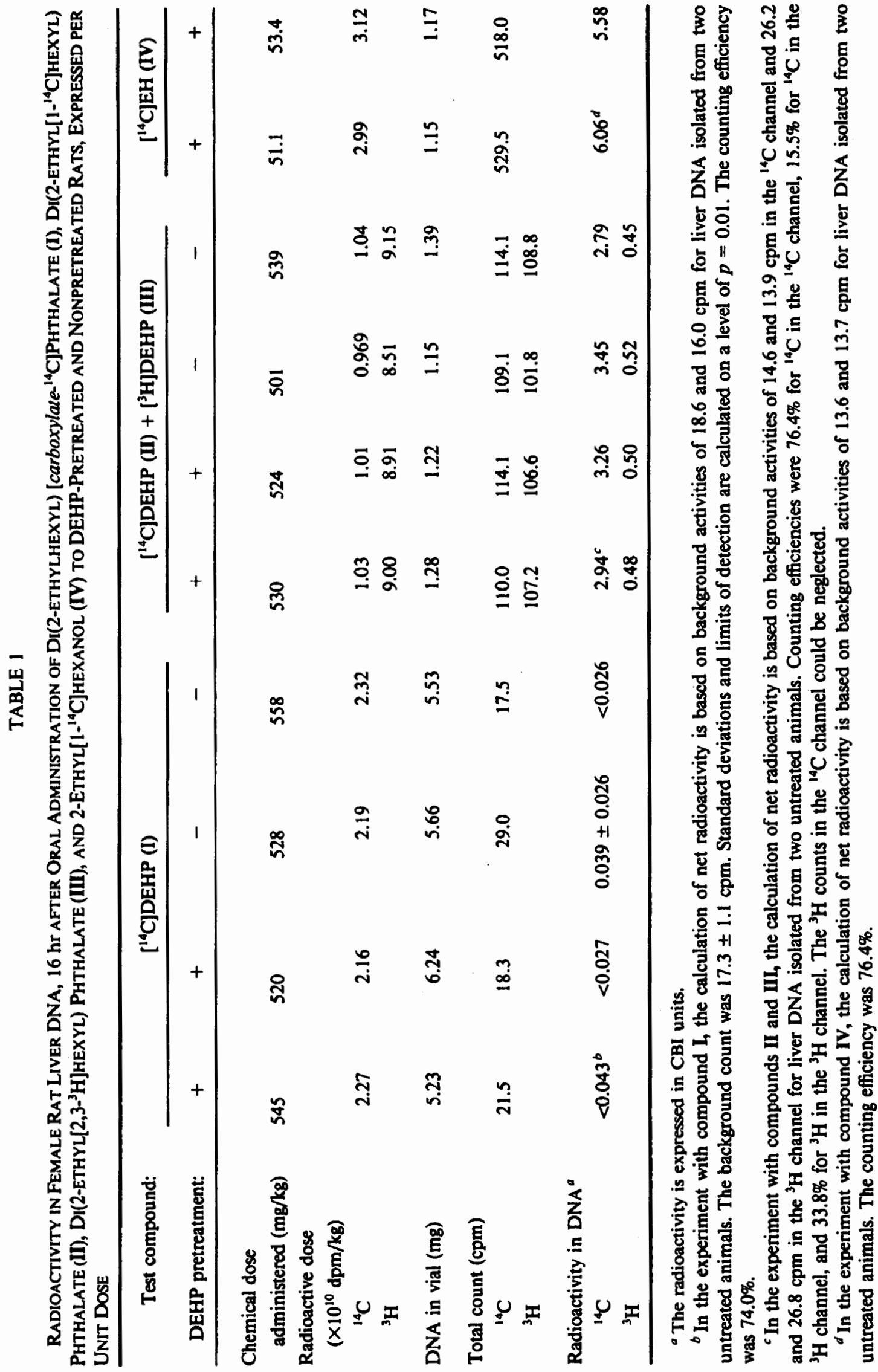


higher than that of DNA which is known to be contaminated by a maximum of $0.2 \%$ protein (Sagelsdorff et al., 1983).

The relatively high ${ }^{14} \mathrm{CO}_{2}$ production seen after administration of DEHP II and EH IV indicates that a large fraction of the alcohol moiety is degraded in the body. The degradation products may then be used as precursors in the biosynthesis of the deoxyribonucleosides. After oral administration of $\left[{ }^{14} \mathrm{C}\right]$ methanol to rats, the ${ }^{14} \mathrm{CO}_{2}$ exhalation amounted to $80 \%$ of the dose. The radioactivity in the liver DNA isolated $12 \mathrm{hr}$ after the administration of $\left[{ }^{14} \mathrm{C}\right]$ methanol corresponded to a CBI of 170 (Däniken et al., 1981). The ${ }^{14} \mathrm{CO}_{2}$ exhaled after $\left[{ }^{14} \mathrm{C}\right] \mathrm{CEHP}$ administration was 25-50 times smaller, in the range of $1.5-3 \%$ of the dose. A CBI in the region of 3-6 may therefore easily be explained on the basis of biosynthetic incorporation. This finding is in perfect agreement with the values around 3 as measured here (Table 1).

The ${ }^{3} \mathrm{H}$ radioactivity in the DNA measured after the administration of $\left[{ }^{3} \mathrm{H}\right] \mathrm{DEHP}$ III was about 12 times lower than the ${ }^{14} \mathrm{C}$ radioactivity originating from DEHP II. Again, this radioactivity was shown to result primarily from biosynthetic incorporation into DNA of tritiated breakdown products produced during the oxidation of the labeled hexanol. Tritiated water was also shown to be formed and the specific activity of HTO in the 16-hr urine was about $2 \times 10^{7} \mathrm{dpm} / \mathrm{ml}$. Control experiments with oral administration of HTO and isolation of liver DNA after $24 \mathrm{hr}$ revealed that radiolabel is associated with the DNA on an apparent CBI level of 0.5 (Lutz, 1979). This radioactivity is not lost from the DNA upon washing so that it does not represent simple proton-tritium ion exchange. One possibility for the formation of a stable carbon-tritium bond is given for instance by the reduction of the 2'-hydroxyl group of the ribonucleoside diphosphate to the 2 -deoxy derivative of DNA. A quantitative comparison similar to the one calculated above with the ${ }^{14} \mathrm{C}$ label is rendered more complicated, however, because the HTO formed in the liver cell from oxidative metabolism of DEHP III reaches a higher intracellular concentration as compared with HTO distributed uniformly after oral administration.

Although the above discussion clearly indicates that ${ }^{14} \mathrm{C}$ and ${ }^{3} \mathrm{H}$ radioactivities in the DNA isolated after administration of alcohollabeled DEHP II and III can be explained by reasons other than covalent interaction of reactive metabolites, this hypothesis had to be corroborated on the basis of an analysis of DNA constituents.

Analysis of nucleosides. An analysis of deoxyribonucleosides was carried out with the DNA obtained from rats treated with ${ }^{14} \mathrm{C}$ - and ${ }^{3} \mathrm{H}$-labeled DEHP II and III and ${ }^{14} \mathrm{C}$-labeled EH IV. The elution of the natural deoxyribonucleosides localized by their optical density at $254 \mathrm{~nm}$ was the same for all DNA samples and is shown on the bottom of Figs. 6 and 7 . Retention times of 8.5 min for deoxycytidine (dC), $11.5 \mathrm{~min}$ for deoxyguanosine (dG), 13.5 min for thymidine (T), and $18 \mathrm{~min}$ for deoxyadenosine (dA) were recorded. The peak appearing at $10.0 \mathrm{~min}$ represented deoxyinosine (dI) which was formed in variable amounts during the hydrolysis of the DNA by enzymatic deamination of deoxyadenosine by enzyme impurities.

Figure 6 shows the elution of the ${ }^{14} \mathrm{C}$ and ${ }^{3} \mathrm{H}$ radioactivity of the digested DNA of animals that had been given alcohol-labeled DEHP (II plus III). It can readily be seen that no radioactivity elutes after deoxyadenosine, i.e., in the region known to contain the more lipophilic deoxyribonucleoside-carcinogen adducts, derived for example from benzo[a]pyrene (Jennette et al., 1977; Boroujerdi et al., 1981), dimethylbenz[a] anthracene (Jeffrey et al., 1976), or 3-methylcholanthrene (King et al., 1977). Radioactivity eluted exclusively with the front peak and with natural nucleosides. The fractions containing the natural nucleosides amounted to the largest part of the total radioactivity eluted, representing 87 to $97 \%{ }^{14} \mathrm{C}$ and 42 to $69 \%{ }^{3} \mathrm{H}$. If these radioactivities, clearly due to biosynthetic incorporation of radiolabeled DEHP-breakdown 

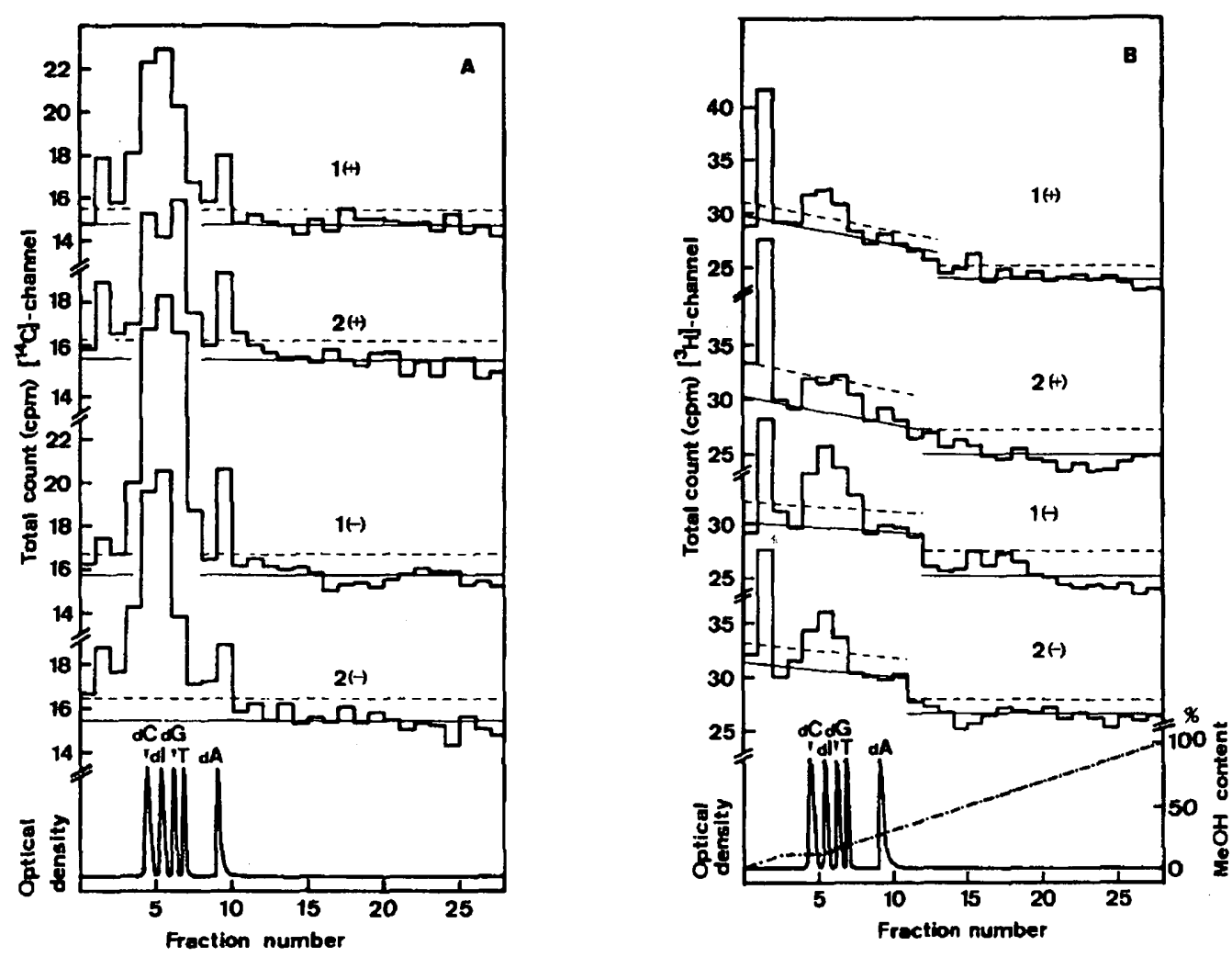

FIG. 6. HPLC elution profiles of deoxyribonucleosides obtained from enzymatically degraded liver DNA. Four rats had been orally administered DEHP (II plus III), ${ }^{14} \mathrm{C}$ - and ${ }^{3} \mathrm{H}$-labeled in the alcohol moiety, two with $(+)$ and two without $(-)$ pretreatment with unlabeled DEHP. The optical density profile (254 $\mathrm{nm}$; bottom diagram) was identical for all four samples. The solid line indicates the level of background radioactivity; the dashed line shows the limit of detection of the radioactivity in the different chromatograms. (A) ${ }^{14} \mathrm{C}$ channel; (B) ${ }^{3} \mathrm{H}$ channel.

products, are deducted from the total apparent $\mathrm{CBI}$ as given in Table 1, residual values of 0.1 to 0.5 and 0.2 to 0.3 for ${ }^{14} \mathrm{C}$ and ${ }^{3} \mathrm{H}$, respectively, result. This view is the most conservative approach based on the assumption that the front peak is due to some sort of DNA adduct formed by the alcohol moiety of DEHP.

These front fractions, No. 2 plus No. 3 of the deoxyribonucleoside chromatograms, contained 3-13 and 31-58\% of the ${ }^{14} \mathrm{C}$ and ${ }^{3} \mathrm{H}$ radioactivity, respectively. Such early eluting radioactivity is generally observed in HPLC analyses of DNA degradation products. It could be due to tightly but noncovalently bound DEHP metabolites, including tritiated water, released from the DNA only after breakdown to the nucleosides. It is also possible that it contains oligo-nucleotides formed by incomplete enzymatic degradation, or sugars produced from degradation of apurinic acid. The latter DNA fragments could have their radioactivity from either biosynthetic incorporation or covalently bound test substance.

The same situation was observed with $\left[{ }^{14} \mathrm{C}\right]$ ethylhexanol IV (Fig. 7). After deduction of the biosynthetic incorporation of radiolabel (83 to $90 \%$ of the total specific activity), a maximum possible CBI of 0.6 to 0.9 could result. In this experiment all deoxyadenosine had been converted to deoxyinosine.

Another way of estimating maximum possible CBI could be based upon the general assumption that carcinogen-deoxyribonucleoside adducts are expected to elute only after $20 \mathrm{~min}$ in the region of fractions $11-28$, due to a higher lipophilicity of such adducts. No 


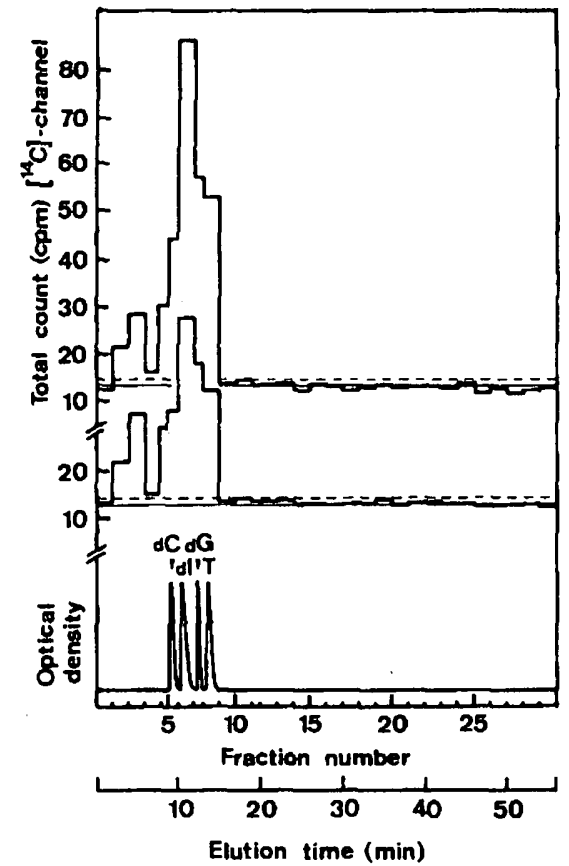

FIG. 7. HPLC elution profile of deoxyribonucleosides obtained from enzymatically degraded liver DNA. Two rats had been orally administered $\left[{ }^{14} \mathrm{C}\right] \mathrm{EH} \mathrm{IV}$, after pretreatment with unlabeled DEHP. The optical density profile ( $254 \mathrm{~nm}$; bottom diagram) was identical for the two samples. The solid line indicates the level of background radioactivity; the dashed line shows the limit of detection of the radioactivity in the different chromatograms.

radioactivity could be detected in this region. On the basis of the standard deviation of the background radioactivity (dashed line in Figs. 6 and 7), a limit of detection for a possible carcinogen-deoxyribonucleoside adduct can be given. The maximum CBI of DEHP is then below 0.07 for $\left[{ }^{14} \mathrm{C}\right] \mathrm{DEHP}$ II, below 0.04 for $\left[{ }^{3} \mathrm{H}\right] \mathrm{DEHP}$ III, and below 0.03 for $\left[{ }^{14} \mathrm{C}\right] \mathrm{EH}$ IV. This limit of detection is therefore almost as low as that of the carboxylate-labeled DEHP I.

Analysis of purines. The above discussion is based upon the general knowledge that nucleoside adducts of typical genotoxic carcinogens such as benzo[a]pyrene, dimethylbenz [a] anthracene, or 3-methylcholanthrene elute after the natural nucleosides, due to increased lipophilicity. It is possible that smaller adducts such as methylated or ethylated nucleosides would not elute much later than the parent natural nucleoside. Therefore, a purine base analysis was performed after acid hydrolysis of two DNA samples of two animals treated with DEHP II plus III, one each with and without DEHP pretreatment. The HPLC system chosen was known to separate 7-methylor 7-ethylguanine, the most abundant alkylation products in DNA, from their parent base. The elution profile is shown in Fig. 8. No radioactivity was detectable at elution volumes known for methylated or ethylated products and a limit of detection was CBI $<0.05$ and $<0.09$ for $\left[{ }^{14} \mathrm{C}\right] \mathrm{DEHP}$ II and CBI $<0.03$ and $<0.05$ for $\left[{ }^{3} \mathrm{H}\right] \mathrm{DEHP}$ III, with and without DEHP pretreatment, respectively.

\section{DNA-Binding Studies in the Mouse}

The data on the radioactivity determined in the mouse liver DNA are summarized in Table 2. With $\left[{ }^{14} \mathrm{C}\right] \mathrm{DEHA} \mathrm{V}$ and $\left[{ }^{3} \mathrm{H}\right] \mathrm{DEHA}$ VI, DNA radioactivity was detectable in all

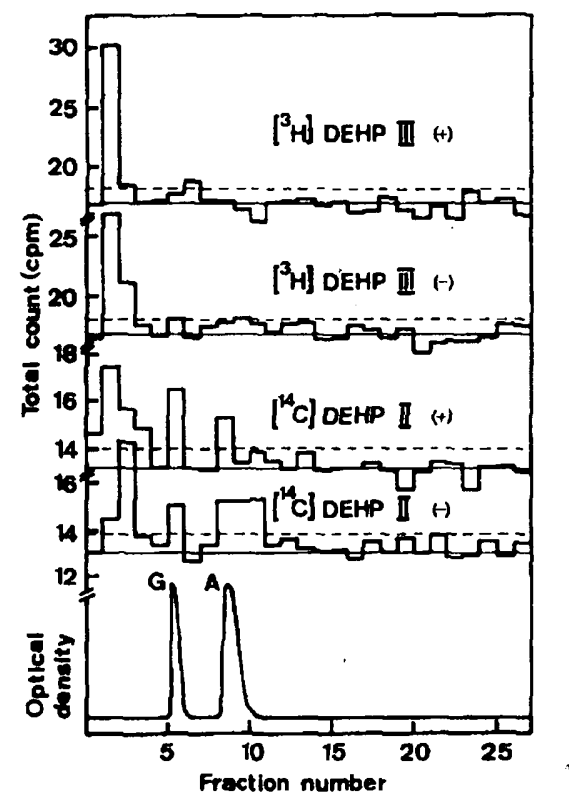

FIG. 8. HPLC elution profile of purine bases obtained from acid-hydrolyzed liver DNA. Rats have been orally administered $\left[{ }^{14} \mathrm{C}\right]$ - and $\left[{ }^{3} \mathrm{H}\right] \mathrm{DEHP}$ (II plus III), one with $(+)$ and one without $(-)$ pretreatment with unlabeled DEHP. The optical density profile ( $254 \mathrm{~nm}$; bottom diagram) was identical for the two samples. The solid line indicates the level of background radioactivity; the dashed line shows the limit of detection of the radioactivity in the different chromatograms. 


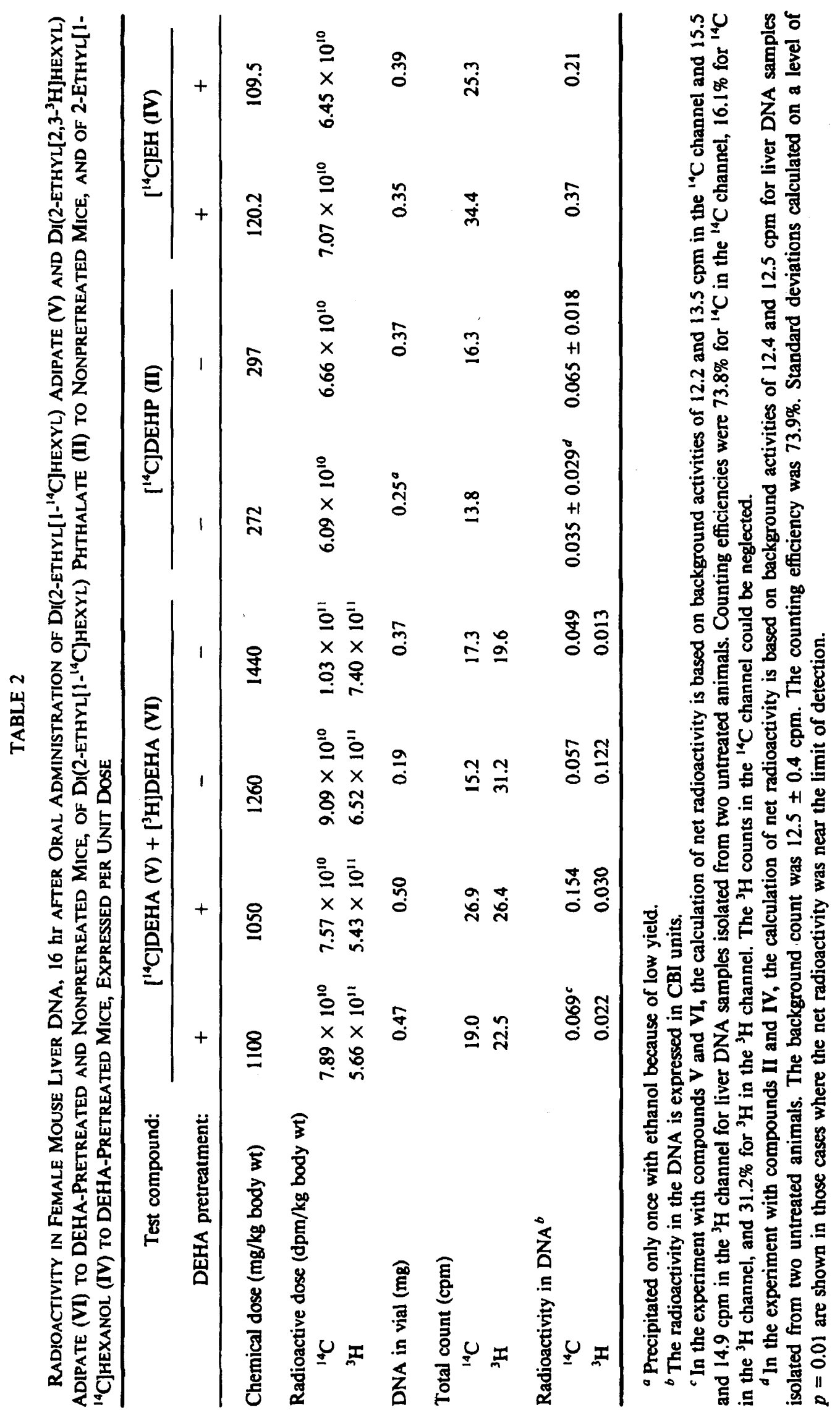


samples. Upon comparison of individual values, the ${ }^{3} \mathrm{H}$ value of one nonpretreated animal was almost ten times higher than that of the other. It is likely that this vial contained traces of ${ }^{3} \mathrm{H}$ radioactivity not due to the DNA sample because the ${ }^{14} \mathrm{C}$ levels were similar, and the ${ }^{14} \mathrm{C}$ to ${ }^{3} \mathrm{H}$ ratio of all other DNA samples was between 3 and 5 whereas that specific DNA sample showed a ratio of 0.5 . By not taking into consideration this probably contaminated tritium value, apparent binding indices in CBI units of $0.05-0.15$ and $0.01-0.03$ resulted for the ${ }^{14} \mathrm{C}$ and ${ }^{3} \mathrm{H}$ label, respectively.

Although radioactivity in the DNA was detectable in all experiments, the specific activities were minute $\left(<50 \mathrm{dpm} / \mathrm{mg}\right.$ DNA for ${ }^{3} \mathrm{H}$ and $<38 \mathrm{dpm} / \mathrm{mg}$ for ${ }^{14} \mathrm{C}$ ) after administration of extremely large doses of radioactivity ( $>5$ $\times 10^{11}$ and $>7 \times 10^{10} \mathrm{dpm} / \mathrm{kg}$ body wt, re. spectively). It was therefore useless to degrade the DNA to nucleosides or bases because the HPLC analysis would not have allowed the determination of the fraction of radioactivity which was incorporated into DNA via biosynthesis. The only possibility for a quantitative estimation of that source of radioactivity was by measuring the formation of ${ }^{14} \mathrm{CO}_{2}$ and HTO. The $\mathrm{CO}_{2}$ data compiled in Fig. 5 show that the DNA radioactivities were proportional to the initial rate of expiration of ${ }^{14} \mathrm{C}$ label. This finding is a good indication that biosynthetic incorporation of radiolabeled breakdown products was the main reason for the DNA labeling.

The experiment with alcohol-labeled $\left[{ }^{14} \mathrm{C}\right] \mathrm{DEHP}$ II in the mouse was performed to establish a link to the results obtained with rats. There, the radioactivity in the liver DNA expressed in CBI units was about 3 as opposed to the mean value of 0.05 for mouse (Tables 1 and 2). The difference by a factor of about 60 is due first to a species difference of about one order of magnitude for biosynthetic incorporation of ${ }^{14} \mathrm{CO}_{2}$ into liver DNA as found earlier in control experiments with oral administration of $\left[{ }^{14} \mathrm{C}\right]$ methanol to mice and rats (data not shown), and second, to the fact that the production of ${ }^{14} \mathrm{CO}_{2}$ was about twice as high in the rat. The specific activity of the liver DNA isolated from the rats was high enough to allow proof that the natural deoxyribonucleosides were radiolabeled (Fig. 6). The DNA radioactivity measurable on the liver DNA of mice treated with $\left[{ }^{14} \mathrm{C}\right] \mathrm{DEHP}$ II is therefore most likely also due to biosynthetic incorporation of radiolabeled breakdown products into DNA. The same argument holds for the results obtained after administration of $\left[{ }^{14} \mathrm{C}\right] \mathrm{EH}$ IV.

The tritium radioactivity in the DNA measured after the administration of $\left[{ }^{3} \mathrm{H}\right] \mathrm{DEHA}$ VI was three to five times lower than the ${ }^{14} \mathrm{C}$ radioactivity originating from DEHA $V$ if the specific activities are normalized to the dose administered by using CBI units. Again, the tritium radioactivity could result from biosynthetic incorporation into DNA of tritiated breakdown products, produced during the oxidation of the labeled hexanol. Tritiated water was shown to be formed and the specific activity of HTO in urine was between 1 and 4 $\times 10^{7} \mathrm{dpm} / \mathrm{ml}$. This level could be achieved from an oxidation and release of 1 to $4 \%$ of the ${ }^{3} \mathrm{H}$ activity administered. This fraction is in good agreement with the fraction of the ${ }^{14} \mathrm{C}$ radioactivity expired in the form of $\mathrm{CO}_{2}$. Control experiments with oral administration of HTO to mice and isolation of liver DNA after $24 \mathrm{hr}$ revealed that radiolabel is indeed incorporated in the natural deoxyribonucleosides on an apparent CBI of 0.05 (Sagelsdorff, 1982). A quantitative comparison similar to the one performed above with the ${ }^{14} \mathrm{C}$ label is rendered more complicated, however, because the HTO formed in the liver cell from oxidative metabolism of DEHA II will reach a higher intracellular concentration compared to HTO distributed uniformly after oral administration.

If all the evidence presented above is taken into account, there is little doubt that negligible or none of the DNA radioactivity detected after administration of $\left[{ }^{14} \mathrm{C}\right]-$ and $\left[{ }^{3} \mathrm{H}\right] \mathrm{DEHA}$ can be due to covalent interactions. Any true 
covalent binding of DEHA to mouse liver DNA will therefore be below CBI $<0.01$.

\section{DISCUSSION}

Our data do not give any indication for a covalent binding of DEHP and DEHA to liver DNA of rats and mice, respectively. Nucleoside and base analyses as well as correlations obtained between ${ }^{14} \mathrm{CO}_{2}$ expired and specific activity of DNA, in both rats and mice, allowed us to conclude that the radioactivity associated with the DNA was largely due to biosynthetic incorporation of radiolabeled breakdown products. $\left[{ }^{14} \mathrm{C}\right] \mathrm{EH}$ administration gave rise to the highest DNA radioactivities and to the highest level of ${ }^{14} \mathrm{CO}_{2}$ exhalation. This result is in contrast to the data reported by Albro et al. (1982), where only RNA but not DNA was found to be radiolabeled after administration of $\left[{ }^{14} \mathrm{C}\right] \mathrm{EH}$. Although the amount of radioactivity administered was much smaller than in our experiments, it should have been possible to measure radioactivity in the DNA because Albro et al. (1982) did detect radioactivity in the DNA after a similar radioactive dose of $\left[{ }^{14} \mathrm{C}\right] \mathrm{DEHP}$ II. Furthermore, in an additional experiment with mono(2-ethyl[ $\left.1-{ }^{14} \mathrm{C}\right]$ hexyl) phthalate, they did measure radioactivity in both types of nucleic acids and the radioactivity in RNA was very similar to the value measured after administration of $\left[{ }^{14} \mathrm{C}\right] \mathrm{EH}$. This contrast is not readily explained since both nucleic acids contain the same nucleophilic centers, and the biosynthetic incorporation into RNA is unlikely to change so drastically from one experiment to another. We cannot explain their findings.

The subsequent report published by this group (Albro et al., 1983) does not provide any clue to solve the above controversy, but their new findings with alcohol-dual-labeled DEHP at least allowed the conclusion that the intact 2-ethylhexanol side chain cannot simply be attached to DNA. They showed, in addition, that urea isolated from the urine was
${ }^{14} \mathrm{C}$-labeled, suggesting that the DNA could have been radiolabeled via biosynthesis.

\section{Influence of the Pretreatment}

The specific activity of DNA, most if not all due to biosynthetic incorporation of radiolabeled breakdown products, was not affected by DEHP pretreatment of the rats or by DEHA pretreatment of the mice for 4 weeks with $1 \%$ in the diet. The liver weight, on the other hand, was increased after pretreatment. This finding means that DNA synthesis per unit liver weight was no longer stimulated after 4 weeks but seemed to be in stationary phase no different from controls.

The fraction of the radioactivity dose exhaled in the form of ${ }^{14} \mathrm{CO}_{2}$ was larger after pretreatment by factors of 1.4 (DEHP I), 2.1 (DEHP II), and 1.5 (DEHA V). The liver was enlarged by factors of 1.5 (DEHP I) and 1.4 (DEHP II) in the rat and 1.3 (DEHA V) in the mouse. The metabolic activity per unit liver weight therefore did not increase at all or only to a very small extent. DEHP therefore seems not to be an effective inducer of its own metabolism. This finding confirms indirectly other data which show that peroxisomes can be induced without a marked effect on some cytochrome $P$-450-dependent activities (Walseth et al., 1982).

\section{The Covalent Binding Index}

The expression of a DNA binding normalized by the dose in the units of the covalent binding index, CBI, was introduced in 1977 (Lutz and Schlatter, 1977a) for a comparison of the DNA-binding activities of various chemicals tested in a number of laboratories under widely different conditions. The values measured so far span about five orders of magnitude, ranging from more than $10^{4}$ [aflatoxin $B_{1}$ (Lutz et al., 1980)] down to about one [e.g. benzene (Lutz and Schlatter, 1977b)]. CBIs have been shown to reflect very roughly 
the genotoxic potency of a chemical. CBIs of the order of $10^{3}$ to $10^{4}$ are found with potent carcinogens, of around $10^{2}$ for moderate carcinogens, and of 1 to 10 for weak carcinogens with a genotoxic mode of action. A plot of the CBI in the target organ as a function of the respective tumorigenic potency in TD50 units derived from long-term bioassays on carcinogenicity has been set up with 13 chemicals for which both values were published (Lutz, 1982a). The surprisingly high correlation coefficient of 0.74 calculated from a linear regression analysis therefore seems to allow placement of a test compound into a category according to the importance of DNA binding as one factor contributing to the overall tumorigenicity.

Our results allow the conclusion that the liver DNA-binding ability of DEHP in rats and of DEHA in mice must be well below a value of 0.05 , expressed in CBI units. This is almost one million times below the genotoxicity of aflatoxin $B_{1}$, where daily doses of as little as $10^{-5} \mathrm{mmol} / \mathrm{kg}$ resulted in detectable tumor formation. If the much lower maximum possible DNA binding by DEHP and DEHA should become responsible for a positive result in a rodent bioassay on carcinogenicity, impossibly high doses or an unrealistically large number of animals would be required if the correlation of carcinogenic potency to DNA binding is extrapolated to a CBI value of 0.05 (Lutz, 1982a).

The fact that a tumorigenicity of DEHP and DEHA has clearly been demonstrated, however, is an indication that activities other than DNA binding of the test compound must be responsible. The observation that induction of peroxisomes is associated with increased hepatic tumor formation (Reddy et al., 1980) and the finding of an excessive accumulation of autofluorescent lipofuscin in the liver during hepatocarcinogenesis by peroxisome proliferators (Reddy et al., 1982) led these authors to the hypothesis that persistent proliferation of peroxisomes and increase in peroxisomal $\beta$-oxidation systems could serve as an endog- enous initiator of the neoplastic transformation of liver cells by increasing the intracellular production of DNA-damaging $\mathrm{H}_{2} \mathrm{O}_{2}$ and other reactive oxygen intermediates.

A DNA-binding assay in vivo finds an important application where a long-term assay on carcinogenicity was clearly positive, but where additional information, such as mutagenicity data, renders a genotoxic mode of action via DNA binding unlikely (Lutz, 1982b). These requirements are met with DEHP and DEHA. Here, it was important to verify the lack of DNA binding of the compound also in a mammalian organism. Negative results as shown above suggest that the tumorigenicity might have been dependent on the onset of some type of biological response which should also have been observable in the bioassay. With DEHP and DEHA, this response could well be the proliferation of peroxisomes. For an assessment of the risk for man from exposure to this type of carcinogen, it will therefore be important to establish doseeffect relationships and to further substantiate the importance of species differences.

\section{REFERENCES}

Albro, P. W., Corbett, J. T., SChroeder, J. L., JoRDAN, S., AND MATthews, H. B. (1982). Pharmacokinetics, interactions with macromolecules and species differencies in metabolism of DEHP. Environ. Health Perspect. 45, 19-25.

Albro, P. W., Corbett, J. T., SChroeder, J. L., AND JORDAN, S. T. (1983). Incorporation of radioactivity from labeled di-(2-ethylhexyl)phthalate into DNA of rat liver in vivo. Chem.-Biol. Interact. 44, 1-16.

Boroujerdi, M., KUNG, H.-C., WILSON, A. G. E., AND ANDERSON, M. W. (1981). Metabolism and DNA binding of benzo(a)pyrene in vivo in the rat. Cancer Res. 41, 951-957.

CARPENTER, C. P., WeIl, C. S., AND SMYTH, H. F. (1953). Chronic oral toxicity of di(2-ethylhexyl)phthalate for rats, guinea pigs and dogs. Arch. Ind. Hyg. Occup. Med. 8, 219-226.

DÄNIKEN, A., LUTZ, W. K., AND SCHLATTER, C. (1981). Lack of covalent binding to rat liver DNA of the hypolipidemic drugs clofibrate and fenofibrate. Toxicol. Lett. 7, 305-310.

Gray, T. J. B., Beamand, J. A., Lake, B. G., Foster, 
J. R., AND Gangoll, S. D. (1982). Peroxisome proliferation in cultured rat hepatocytes produced by clofibrate and phthalate ester metabolites. Toxicol. Lett. 10, 273-279.

HaRris, R. S., Hodge, H. C., Maynard, E. A., AND BLANCHET, H. J. (1956). Chronic oral toxicity of 2ethylhexyl phthalate in rats and dogs. Arch. Ind. Health 13, 259-264.

JeFFREY, A. M., Blobstein, S. H., Weinstein, I. B., AND HARVEY, R. G. (1976). High pressure liquid chromatography of carcinogen-nucleoside conjugates: Separation of 7,12-dimethylbenzanthracene derivatives. Anal. Biochem. 73, 378-385.

JeNNETTE, K. W., JefFrey, A. M., BLobStein, S. H., BELAND, F. A., HARvey, R. G., AND WEINSTEIN, I. B. (1977). Nucleoside adducts from the in vitro reaction of benzo(a)pyrene-7,8-dihydrodiol 9,10-oxide or benzo(a)pyrene-4,5-oxide with nucleic acids. Biochemistry 16, 932-938.

KaISER, H. (1965). Zum Problem der Nachweisgrenze. Z. Anal. Chem. 209, 1-18.

KING, H. W. S., OSBORNE, M. R., AND BroOKes, P. (1977). The metabolism and DNA binding of 3-meth ylcholanthrene. Int. J. Cancer 20, 564-571.

LUTz, W. K. (1979). In vivo covalent binding of organic chemicals to DNA as a quantitative indicator in the process of chemical carcinogenesis. Mutation Res. 65 , 289-356.

LUTZ, W. K. (1982a). Constitutive and cancinogen-derived DNA binding as a basis for the assessment of potency of chemical carcinogens. In Biological Reactive Intermediates II (R. Snyder, D. V. Parke, J. J. Kocsis, D. J. Jollow, C. G. Gibson, and C. M. Witmer, eds.), Part B, pp. 1349-1365. Plenum, New York.

LuTz, W. K. (1982b). The covalent binding index-DNA binding in vivo as a quantitative indicator for genotoxicity. In Banbury Report No. 13, Indicators of Genotoxic Exposure (B. A. Bridges, B. E. Butterworth, and I. B. Weinstein, eds.). pp. 189-204. Cold Spring Harbor Laboratory, Cold Spring Harbor, N.Y.

LUTZ, W. K., AND SCHLATTER, C. (1977a). Saccharin does not bind to DNA of liver or bladder in the rat. Chem.-Biol. Interact. 19, 253-257.

LuTz, W. K., AND SCHLATTER, C. (1977b). Mechanism of the carcinogenic action of benzene: irreversible binding to rat liver DNA. Chem.-Biol. Interact. 18, 241245.

LuTz, W. K., JagGi, W., LUThy, J., Sagelsdorff, P., AND SCHLATTER, C. (1980). In vivo covalent binding of aflatoxin $B_{1}$ and aflatoxin $M_{1}$ to liver DNA of rat, mouse and pig. Chem.-Biol. Interact. 32, 249-256.

MANGHAM, B. A., Foster, J. R., AND LAKE, B. G. (1981). Comparison of the hepatic and testicular effects of orally administered di(2-ethylhexyl)phthalate and dialkyl- phthalate in the rat. Toxicol. Appl. Pharmacol.61, 205214.

MARKov, G. G., AND IVANOv, I. G. (1974). Hydroxyapatite column chromatography in procedures for isolation of purified DNA. Anal. Biochem. 59, 555-563.

MEIER-BRATSCHl, A., LUTZ, W. K., AND SCHLATTER, C. (1983). Methylation of liver DNA of rat and mouse by $N$-nitrosodimethylamine formed in vivo from dimethylamine and nitrite. Food Chem. Toxicol. 21, 285-289.

MOODY, D. E., AND REDDY, J. K. (1978). Hepatic peroxisome (microbody) proliferation in rats fed plasticizers and related compounds. Toxicol. Appl. Pharmacol. 45, 497-504.

National Toxicology Program. (1982a). Carcinogenesis Bioassay of Di(2-ethylhexyl)phthalate (CAS NO. 117. 81-7) in F344 Rats and B6C3Fl Mice (Feed Study), Technical Report Series No. 217, NIH Publ. No. 821773. USDHHS, PHS, NIH, Research Triangle Park, N.C.

National Toxicology Program. (1982b). Carcinogenesis bioassay of Di(2-ethylhexyl)-adipate (CAS NO. 103-231). Technical Report Series No. 212, NIH Publ. No. 81-1768. USDHHS, PHS, NIH, Research Triangle Park, N.C.

REDDY, J. K. (1981). Toxicologic implications of drug induced hepatic peroxisome proliferation. In Lectures in Toxicology (G. Zbinden, ed.), Vol. 8, pp. 1-11. Pergamon, New York.

REDDY, J. K., AZARNOFF, D. L., AND HIGNITE, C. E. (1980). Hypolipidemic hepatic peroxisome proliferators form a novel class of chemical carcinogens. Nature (London) 283, 397-398.

REDDY, J. K., LALWANI, N. D., REDDY, M. K., AND QURESHI, S. A. (1982). Excessive accumulation of autofluorescent lipofuscin in the liver during hepatocarcinogenesis by methyl clofenapate and other hypolipidemic peroxisome proliferators. Cancer Res. 42, 259266.

SAGELSDORFF, P. (1982). Bedeutung der kovalenten DNS. Bindung oder anderer Mechanismen bei der Erzeugung von Lebertumoren durch die Isomeren von Hexachlorcyclohexan. Ph.D. thesis, Diss. ETH No. 7127, Eidgenössische Technische Hochschule, Zürich.

SAGElSDORFF, P., LUTZ, W. K., AND SChLATTER, C. (1983). The relevance of covalent binding to mouse liver DNA to the carcinogenic action of hexachlorocyclohexane isomers. Carcinogenesis 4, 1267-1273.

WALSETH, F., TOFTGARD, R., AND NILSEN, O. G. (1982). Phthalate esters. I. effects on cytochrome $P-450$ mediated metabolism in rat liver and lung, serum enzymatic activities and serum protein levels. Arch. Toxicol. 50, 110.

YANEVA, M., AND Dessev, G. (1976). Isolation and properties of structured chromatin from Guerin ascites tumour and rat liver. Eur. J. Biochem. 66, 535-542. 